\title{
Mengubah Sampah Organik Menjadi Eco Enzym Multifungsi: Inovasi di Kawasan
}

\section{Urban}

\author{
Cucuk Wawan Budiyanto ${ }^{1}$, Annisa Yasmin ${ }^{2}$, Annona Nura Fitdaushi ${ }^{3}$, Asa Qubaila Sitta
}

Zidni Rizqia $^{4}$, Avona Rara Safitri ${ }^{5}$, Devita Nurul Anggraeni ${ }^{6}$, Kharimah Heba Farhana ${ }^{7}$, Maryam Quatly Alkatiri ${ }^{8}$, Yoga Yudha Perwira9, Yoshan Ardhi Pratama ${ }^{10}$

${ }^{1}$ Pendidikan Teknik Informatika dan Komputer, Universitas Sebelas Maret, Indonesia, ${ }^{2}$ Agroteknologi, Universitas Sebelas Maret, Indonesia, ${ }^{3}$ Agroteknologi, Universitas Sebelas Maret, Indonesia, ${ }^{4}$ Sastra Arab, Universitas Sebelas Maret, Indonesia, ${ }^{5}$ Pendidikan Bahasa Jawa, Universitas Sebelas Maret, Indonesia, ${ }^{6}$ S1 Farmasi, Universitas Sebelas Maret, Indonesia,

${ }^{7}$ Pendidikan Pancasila dan Kewarganegaraan, Universitas Sebelas Maret, Indonesia, ${ }^{8} \mathrm{~S} 1$

Farmasi, Universitas Sebelas Maret, Indonesia, ${ }^{9}$ Pendidikan Kepelatihan Olahraga, Universitas

Sebelas Maret, Indonesia, ${ }^{10}$ Teknik Industri, Universitas Sebelas Maret, Indonesia

Corresponding email : cbudiyanto@staff.uns.ac.id

\begin{abstract}
The waste in urban areas was the concern in the KKN UNS Membangun. Around $80 \%$ of the total amount of waste generated is dominated by organic waste which is only seen as waste that has no economic value. Therefore, the community service activity of KKN UNS Membangun Desa Kelompok 37. Sangkrah Village was carried out in the form of socialization and training in the manufacture of eco-enzyme multipurpose liquid. Organic waste can be processed into eco enzyme which is useful as a cleaning liquid, wound treatment, and plant fertilizer. Socialization activities and training on the manufacture of eco-enzyme multipurpose liquid were carried out offline in Sangkrah Village, Pasar Kliwon District, Surakarta, Central Java, Indonesia by implementing strict health protocols. Socialization activities and training on the making of eco enzyme were attended by representatives of the residents to prevent crowds. This activity aims to make the Sangkrah Village community able to utilize organic waste so that it can be used and even can add to the economic value of the surrounding community.
\end{abstract}

Keywords: Community service; Eco enzyme; Multipurpose liquid; Organic waste;

\begin{abstract}
ABSTRAK
Masalah sampah yang ada di perkotaan menjadi perhatian dalam kegiatan KKN UNS Membangun Desa. Sekitar 80\% dari jumlah total sampah yang dihasilkan, didominasi oleh sampah organik yang hanya dipandang sebagai limbah yang tidak memiliki nilai ekonomi. Karena itu kegiatan pengabdian masyarakat KKN UNS Membangun Desa Kelompok 371 Kelurahan Sangkrah dilaksanakan dalam bentuk sosialisasi dan pelatihan pembuatan cairan serbaguna eco enzyme. Sampah organik dapat diolah menjadi eco enzyme yang bermanfaat sebagai cairan pembersih, obat luka, dan pupuk tanaman. Kegiatan sosialisasi dan pelatihan pembuatan cairan serbaguna eco enzyme dilaksanakan di Kelurahan Sangkrah, Kecamatan Pasar Kliwon, Surakarta, Jawa Tengah Indonesia secara luring dengan menerapkan protokol kesehatan yang ketat. Kegiatan sosialisasi dan pelatihan pembuatan eco enzyme dihadiri dari perwakilan warga untuk mencegah adanya kerumunan. Kegiatan ini bertujuan agar masyarakat Kelurahan Sangkrah dapat memanfaatkan sampah organik sehingga dapat dimanfaatkan bahkan dapat menambah nilai ekonomi masyarakat sekitar.
\end{abstract}

Kata kunci: KKN; Eco enzyme; Cairan multifungsi; Sampah organik; 


\section{PENDAHULUAN}

Sampah sudah menjadi masalah umum yang ditemui di kota-kota besar di berbagai dunia, tak terkecuali di Indonesia. Beberapa kota besar di Indonesia sedang bergerak dalam mengatasi permasalahan sampah saat ini diantaranya Jakarta, Bandung, Surabaya, dan tak dipungkiri di Kota Surakarta pun juga. Sekitar $80 \%$ dari jumlah total sampah yang dihasilkan didominasi oleh sampah organik yang hanya dipandang sebagai limbah sisa yang tidak memiliki nilai ekonomi (Pratiwi 2021). Sampah rumah tannga merupakan jenis sampah yang turut andil dalam pencemaran lingkungan. Pengelolaan sampah organik belum dilakukan dengan baik dan masih banyak masyarakat yang membuangnya ke lahan kosong, salurah air, atau dibakar. Padahal, sampah organik jika bisa dikelola dengan baik dapat sangat bermanfaat dan memiliki nilai ekonomi. Menurut Yusuf (2008) seiring meningkatnya aktivitas masyarakat di lingkungannya mampu menyebabkan semakin banyak volume sampah/limbah yang dihasilkan dengan berjalannya waktu.

Berdasarkan hasil observasi selama bulan Juli - Agustus 2021 di RW 04 Kelurahan Sangkrah, Kota Surakarta, ditemukan bahwa sampah rumah tangga, khususnya sampah organik masih belum dikelola dengan baik. Biasanya sampah organik bercampur dengan sampah jenis lain, dibuang langsung ke tempat sampah, atau dibungkus dalam plastik lalu dibuang ke tempat sampah. Volume sampah yang harus diangkut oleh petugas kebersihan ke lokasi Tempat Pembuangan Sampah akhir di TPA Putri Cempo cukup besar.

Dengan pemikiran bahwa sampah organik masih bisa dimanfaatkan dan memberikan nilai tambah, maka Kelompok 371 KKN UNS melakukan kegiatan pengelolaan sampah organik sebagai kegiatan pengabdian dalam KKN UNS Membangun Desa selama bulan Agustus 2021. Kegiatan ini bertujuan untuk mengolah sampah organik dari limbah rumah tangga agar bisa dimanfaatkan sehingga dapat menambah nilai ekonomi masyarakat sekitar dan mengurangi volume sampah oraganik yang dibuang ke Tempat Pembuangan Akhir. Sampah organik diolah menjadi ecoenzym yang berfungsi sebagai pengganti cairan kebersihan, pupuk tanaman, obat luka, dan lain-lain.

\section{TINJAUAN PUSTAKA}

Peningkatan aktivitas masyarakat berpotensi menyebabkan semakin banyak volume sampah/limbah yang dihasilkan (Yusuf, 2008), karena aktivitas manusia tidak akan terlepas dari adanya sampah atau limbah. Sisa-sisa kegiatan manusia atau proses alam yang berbentuk padat atau semi padat dan berupa zat organik atau anorganik yang tidak diperlukan manusia lagi (Megah et al. 2018), menandai keberadaan manusia yang berakibat negative terhadap lingkungan alam. Pada hakikatnya, sampah tidaklah selalu merugikan bagi manusia, bahkan apabila diolah dengan cara yang tepat akan menghasillkan produk yang sesuatu yang sangat bermanfaat. Kegiatan pengolahan sampah yang paling sederhana yang dilakukan kebanyakan masyarakat masih menggunakan cara tradisional atau sederhana dan masih kurang ramah lingkungan. Menurut Yunik'ati et al. (2019) langkah yang paling sederhana untuk pengolahan sampah adalah dengan metode 3R yaitu : Reduce, Reuse, dan Recycle.

Pengolaan sampah menggunakan metode 3R tersebut akan sangat membantu apabila masyarakat telah memilah antara sampah organik dan anorganik. Pemahaman masyarakat tentang pemilahan sampah inilah yang akan membantu masyarakat untuk 
menentukan metode dalam mengolah sampah menjadi sesuatu yang akan bermanfaat. Fakta yang ada, sekitar $80 \%$ dari jumlah total sampah yang dihasilkan didominasi oleh sampah organik yang hanya dipandang sebagai limbah sisa yang tidak memiliki nilai ekonomi (Pratiwi 2021). Pemecahan permasalahan mengenai sampah organik ini adalah dengan salah satunya pengolahan sampah organik menjadi cairan eco enzyme.

Pengolahan sampah organik menjadi eco enzyme merupakan hasil penelitian yang telah dilakukan oleh Dr. Rasukon Poompanvong dari Thailand. Menurut Imron (2020) eco enzyme merupakan hasil dari fermentasi limbah sampah organik seperti ampas buah dan sayuran, gula (gula aren, gula merah, atau gula tebu), dan air. Warnanya coklat gelap dan memiliki bau khas fermentasi asam manis yang kuat. Ecoenzime memiliki manfaat yang berlipat ganda. Dengan memanfaatkan sampah organik sebagai bahan bakunya, kemudian dicampur dengan gula aren dan air, proses fermentasinya menghasilkan gas $\mathrm{O}_{3}$ (ozon) dan hasil akhirnya adalah cairan pembersih serta pupuk yang ramah lingkungan.

\section{METODE}

Metode pelaksanaan kegiatan pengabdian masyarakat oleh Tim KKN UNS Membangun Desa Periode Juli Agustus 2021 ini dilakukan dengan :

Tahap persiapan berupa : 1) Koordinasi bersama ketua RW dan RT setempat terkait teknis dan tempat dilaksanakannya kegiatan, 2) Penyiapan alat dan bahan yang diperlukan, 3) Pemberitahuan informasi kepada perwakilan warga ke setiap RT untuk menghadiri kegiatan.

Tahap Pelaksanaan kegiatan Sosialisasi dan Pelatihan Pembuatan Cairan Serbaguna Eco enzyme dilakukan di halaman rumah kediaman Ketua RT 03 Bapak Rusjamaludin pada hari Senin 23, Agustus 2021. Pelaksanaan sosialisasi dan pelatihan dihadiri perwakilan warga dari RT 01, RT 02, RT 03, dan RT 04 yang berada di RW 04 Kelurahan Sangkrah, Kecamatan Pasar Kliwon, Kotamadya Surakarta.

\section{Formula dan cara membuat cairan serbaguna eco enzyme :}

\section{Formula}

1. Gula merah / gula aren / molase $1 \mathrm{~kg}$

2. Sampah organik (kulit buah, sisa sayuran dan buah) $3 \mathrm{~kg}$

3. Air bersih (air hujan / air galon / air sumur / air PDAM yang sudah didiamkan selama 24 jam / air AC) 6 liter

Note :

Perbandingan bahan-bahan yang digunakan gula merah : sampah organik : air $=1: 3: 6$

\section{Alat-alat yang diperlukan :}

1. Tong atau wadah yang memiliki mulut lebar dan bertutup rapat. (Hidari wadah berbahan kaca, diutamakan menggunakan wadah berbahan plastik).

2. Tongkat untuk pengaduk

\section{Cara membuat cairan serbaguna eco enzyme sebagai berikut :}

1. Pilah-pilah sampah organik yang masih terlihat segar, tidak busuk, tidak keras, dan tidak terdapatbelatung. 
2. Ukur dan timbang bahan-bahan yang diperlukan sesuai dengan formula bahan yang yang telah ditentukan.

3. Masukkan air ke dalam tong.

4. Masukkan gula jawa / gula aren / molase kemudian aduk hingga larut.

5. Masukkan sampah organik kemudian aduk hingga merata dan tutup wadah dengan rapat.

6. Letakkan tong ke tempat yang tidak terkena sinar matahari dan terhindar dari tempat yang kotor serta berbau tajam.

7. Fermentasi bahan dilakukan selama 3 bulan.

8. Setelah fermentasi selesai, ambil cairan hasil fermentasi mengunakan saringan, kemudian sisihkan ampasnya untuk dimanfaatkan sebagai pupuk organik.

9. Simpan cairan fermetasi tersebut ke dalam botol kemasan plastik, kemudian tutup rapat botol.

Menurut Imron (2020) eco enzyme merupakan hasil dari fermentasi limbah sampah organik seperti ampas buah dan sayuran, gula (gula aren, gula merah, atau gula tebu), dan air. Warnanya coklat gelap dan memiliki bau khas fermentasi asam manis yang kuat.Ekoenzimmemilikimanfaat yang berlipat ganda. Dengan memanfaatkan sampah organik sebagai bahan bakunya, kemudian dicampur dengan gula aren dan air, proses fermentasinya menghasilkan gas 03 (ozon) dan hasil akhirnya adalah cairan pembersih serta pupuk yang ramah lingkungan. Proses pembuatan eco enzyme sangat sederhana yaitu hanya dengan menggunakan 3 bahan antara lain sisa buah atau sayur, air, dan gula (gula merah, gula aren, molase). Pembuatannya membutuhkan kontainer berupa wadah yang terbuat darip lastik, penggunaanbahan yang terbuat dari kaca sangat dihindari karena dapat menyebabkan wadah pecah akibat aktivitas mikroba fermentasi. Perbandingan antara ketiga bahan adalah 1:3:6 yaitu membutuhkan $1 \mathrm{~kg}$ gula merah, 3 $\mathrm{kg}$ sisa buah atau sayur, dan $6 \mathrm{~kg}$ air.

\section{HASIL, PEMBAHASAN, DAN DAMPAK}

Kuliah Kerja Nyata (KKN) Universitas Sebelas Maret Surakarta (UNS) Membangun Desa periode Juli-Agustus 2021 resmi dilaksanakan pada tanggal 3-31 Agustus 2021. Kelompok 371 KKN UNS Membangun Desa bertugas di Kelurahan Sangkrah, Kecamatan Pasar Kliwon, Surakarta, Jawa Tengah, mengangkat tema 'SEMAR MENDEM' (Semarak Pemberdayaan Masyarakat di Masa Pandemi. Kelompok 371 ini berada di bawah pengawasan Dosen Pembimbing Lapangan (DPL) Bapak Cucuck Wawan Budiyanto, S.T., Ph.D. dengan koordinator kelompok Yoga Yudha Perwira (FKOR / Pendidikan Kepelatihan Olahraga). Kelompok 371 ini beranggotakan Asa Qubaila Sitta Zidna Rizqia (FIB / Sastra Arab), Avona Rara Safitri (FKIP / Pendidikan Bahasa Jawa), Annona Nura Firdaushi (FP / Agroteknologi), Maryam Qualty Alkatiri (FMIPA / Farmasi), Yoshan Ardhi Pratama (FT / Teknik Industri), Annisa Yasmin (FP/ Agroteknologi), Devita Nurul Anggraeni (FMIPA / Farmasi), dan Kharimah Heba Farhana (FKIP / Pendidikan Pancasila dan Kewarganegaraan).

Kelompok 371 KKN UNS Membangun Desa memiliki 15 program kerja yang terdiri atas 4 program utama dan 11 program penunjang. Salah satu program utama yang dilaksanakan adalah kegiatan Sosialisai dan Pelatihan Pembuatan Cairan Serbaguna Eco enzyme. pelatihan pembuatan eco enzyme dilaksanakan pada hari Senin (23/8/2021) dilaksanakan di kediaman Ketua RT 03 Bapak Rusjamaludin pada pukul 
16.00. Pelatihan pembuatan eco enzyme ini dilaksanakan dengan mematuhi protokol kesehatan Covid-19 ketat, yang hanya dihadiri 2-3 warga dari setiap perwakilan RT. Pelatihan pembuatan eco enzyme ini bertujuan agar masyarakat dapat mengolah sampah organik yang dihasilkan dari rumah tangga menjadi sesuatu yang dapat dimanfaatkan kembali. Pembuatan eco enzyme sangatlah mudah dan dapat dilakukan oleh masyarakat umum, yaitu hanya membutuhkan wadah berbahan plastik yang bermulut lebar dan bertutup rapat, sampah organik (kulit buah, sisa buah, dan sisa sayur), gula jawa / molase, dan air. Proses fermentasi memakan waktu sekitar 3 bulan untuk memperoleh cairan eco enzyme tersebut. Eco enzyme memiliki berbagai manfaat, diantaranya dapat menjadi cairan pembersih lantai, pembersih toilet, sebagai deterjen, sebagai obat pengering luka, bahkan dapat digunakan sebagai handsanitizer.

Pembuatan cairan eco enzyme diawali dengan memilah sampah organik dan menentukan formula bahan-bahan yang diperlukan. Sampah organik yang dapat digunakan untuk membuat eco enzyme memiliki kriteria yaitu : masih terlihat segar, tidak busuk, tidak keras, dan tidak terdapat belatung. Penggunaan sampah organik yang beraroma seperti kulit jeruk dan daun mint dapat menambahan bau khas pada cairan eco enzyme yang akan dihasilkan. Formula bahan-bahan untuk membuat eco enzyme perlu diperhatikan pada perbandingan gula merah : sampah organik : air yaitu $1: 3: 6$. Formulasi bahan yang dibutuhkan adalah $1 \mathrm{~kg}$ gula merah, $3 \mathrm{~kg}$ sampah organik, dan kemudian $6 \mathrm{~kg}$ air yang setara dengan $6 \mathrm{~L}$ air.

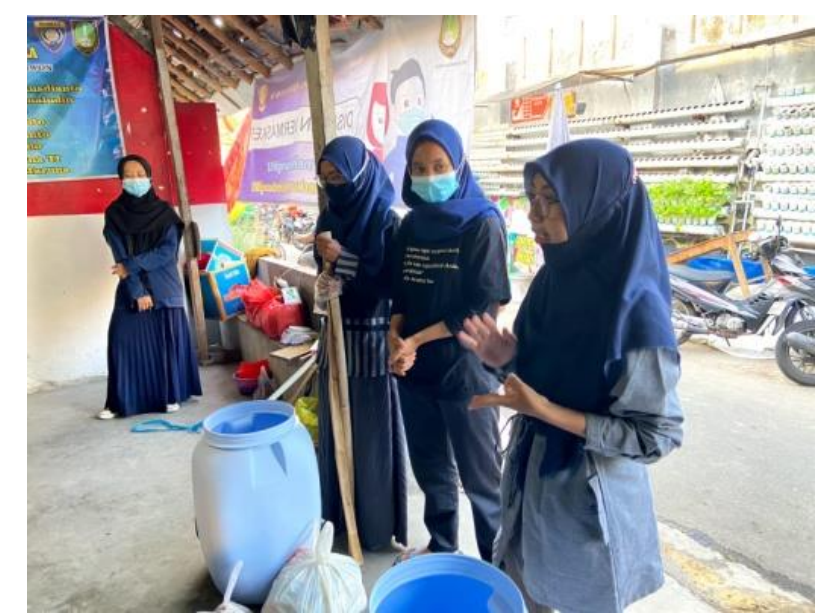

Gambar 1. Penjelasan Singkat Mengenai Kriteria Sampah Organik dan Formula Bahan untuk Membuat Cairan Serbaguna Eco enzyme.

Sumber : Dokumentasi Kegiatan, 2021

Bahan-bahan yang telah sesuai formulasi kemudian dicampurkan pada wadah dengan kriteria tertentu. Wadah yang sesuai untuk membuat eco enzyme adalah wadah yang berbahan plastik, bukan terbuat dari kaca, memiliki mulut yang lebar, dan memiliki tutup yang rapat. Pencampuran bahan diawali dengan memasukkan gula merah ke dalam air di dalam wadah, kemudian diaduk-aduk hingga gula merah benarbenar larut. Sampah organik yang telah dipilah dan ditimbang sesuai dengan perbandingan formulasi, dimasukkan ke dalam wadah kemudian diaduk rata. Hasil campuran tersebut kemudian ditutup rapat, dan disimpan di tempat yang tidak terkena sinar matahari dan berbau menyengat selama dalam kurun waktu 3 bulan. Cairan hasil fermentasi bahan-bahan tersebutlah yang disebut dengan eco enzyme. 


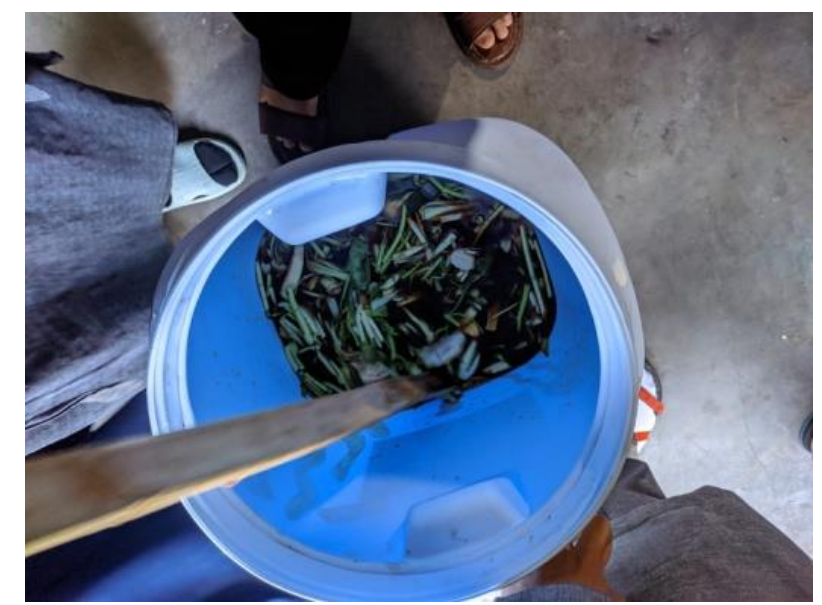

Gambar 2. Pencampuran Bahan-Bahan Eco enzyme

Sumber : Dokumentasi Kegiatan, 2021

Pelaksanaan sosialisasi dan pelatihan pembuatan cairan serbaguna eco enzyme yang dilaksanakan di Kelurahan Sangkrah ini, hanya melibatkan perwakilan warga dari setiap Rukun Tetangga (RT) untuk mencegah adanya kerumunan. Pelaksanaan pelatihan pembuatan eco enzyme pada warga ini dirasa sangat membantu warga untuk mengetahui bagaimana mengolah sampah oragnik terutama yang berasal dari sampah dapur. Keuntungan dari pengolahan sampah organik menjadi eco enzyme adalah masyarakat dapat memenuhi kebutuhan akan cairan pembersih permukaan dan peralatan rumah tangga secara mandiri dan dengan biaya murah. Keuntungan lainnya adalah berkurangnya jumlah sampah yang terbuang sia-sia, sehingga dapat menciptakan kondisi lingkungan yang lebih bersih, nyaman, dan rapi. Produk hasil yaitu eco enzyme ini berpotensi untuk dijual, karena mengingat keberadaan sampah organik rumah tangga warga Kelurahan Sangkrah yang belum dimanfaatkan secara optimal serta bahan-bahan lain yang diperlukan sangat mudah ditemukan di sekitar Kelurahan Sangkrah. Keberlanjutan pembuatan eco enzyme untuk menjadi produk layak jual, tentu saja memerlukan dukungan dan monitoring perangkat desa atau pemerinttah setempat untuk menggerakkan masyarakatnya.

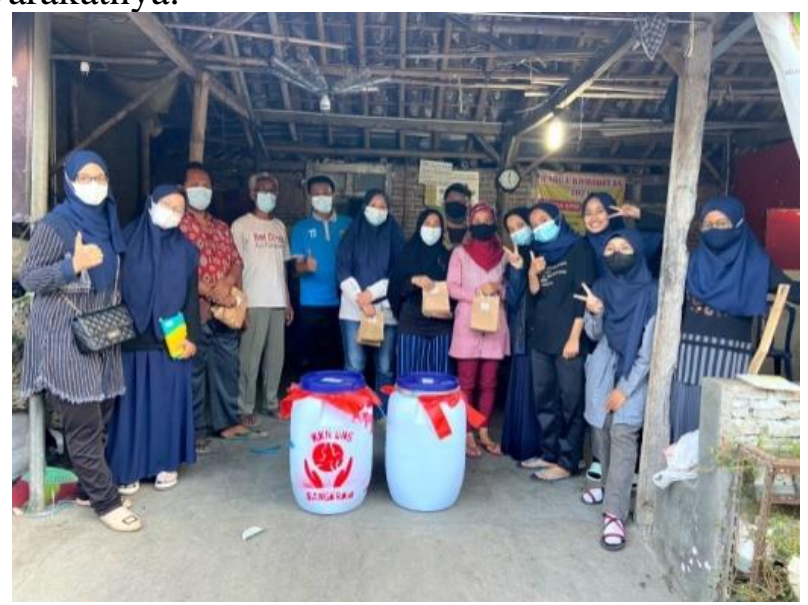

Gambar 3. Peserta Sosialisasi dan Pelatihan Pembuatan Cairan Serbaguna Eco enzyme. Sumber : Dokumentasi Kegiatan, 2021. 
Pengelolaan eco enzyme yang berkelanjutan dapat menjawab permasalahan pemerintah mengenai kebutuhan lingkungan yang bersih (Luthfiyyah et al. 2010). Untuk merealisasikan pengelolaan yang sustainable tersebut, perlu dirancang sebuah konsep yang mensinergikan antara masyarakat dan pemerintah. Konsep yang dapat dibangun adalah pembentukan sebuah komunitas pecinta lingkungan yang memiliki fokus dalam kegiatan pengelolaan sampah organik menjadi eco enzyme. Adanya komunitas tersebut diharapkan masyarakat lebih giat dalam mengelola sampah organik menjadi eco enzyme, selain itu juga berpeluang membuka saluran pemasaran untuk hasil panen eco enzyme sehingga masyarakat dapat merasakan dampak secara ekonomi.

\section{KESIMPULAN}

Dari kegiatan Tim KKN UNS UNS Membangun Desa Kelompok 371 yang dilaksanakan di Kelurahan Sangkrah, Kecamatan Pasar Kliwon, Surakarta dapat disimpulkan bahwa permasalahan sampah yang terjadi di Kawasan perkotaan bisa diatasi dengan penerapan teknologi yang sederhana dan cara kerja yang ringkas tepat guna. Penggunaan teknologi yang sederhana tersebut diharapkan dapat menarik masyarakat untuk berpartisipasi dan tetap meneruskan program tersebut meskipun kegiatan KKN telah berakhir.

Ke depan, diharapkan dilakukan kegiatan lanjutan dari program ini, dalam rangka meningkatkan kapasitas produksi enzyme, dan memasarkan ecoenzym secara lebih luas. Sehingga dampak ekonomis dan social dari pemanfaatan organik dari sampah rumah tangga bisa semakin dirasakan oleh masyarakat yang terlibat.

Kesimpulan dari kegiatan pengabdian masyarakat yang telah dilaksanakan yaitu :

1. Program Kerja pengabdian masyarakat di Kelurahan Sangkrah, Kecamatan Pasar Kliwon, Surakarta oleh Tim KKN UNS Membangun Desa Kelompok 371 dilaksanakan karena ada permasalahan pengolahan sampah organik di masyarakat kota.

2. Sosialisasi dan Pelatihan pembuatan eco enzyme bertujuan agar masyarakat dapat mengolah sampah organik yang dihasilkan dari rumah tangga menjadi sesuatu yang dapat dimanfaatkan kembali.

3. Implikasi dari Sosialisasi dan Pelatihan Pembuatan Eco enzyme yaitu masyarakat dalam melanjutkan kegiatan pembuatan eco enzyme pemerintah kota dapat membentuk sebuah komunitas yang berfokus pada pengelolaan sampah organik.

\section{UCAPAN TERIMAKASIH}

Ucapan terimakasih kepada :

1. UPKKN LPPM Universitas SebelasMaret Surakarta (UNS) yang telah memfasilitasi pelaksanaan KKN UNS Membangun Desa periode Juli-Agustus 2021.

2. Lurah Kelurahan Sangkrah EkoWahyono, S.E. yang telah memberikan tempat dan kesempatan dalam pelaksanaan KKN UNS Membangun Desa periode Juli-Agustus 2021 Kelompok 371.

3. Perwakilan warga RW 04 Kelurahan Sangkrah yang telah turut berpartisipasi dalam kegiatan ini. 


\section{DAFTAR PUSTAKA}

Imron, M. (2020). Manajemen sampah. https://zerowaste.id/zero-waste-lifestyle/ecoenzyme/

Luthfiyyah, A., P, Y. S., \& Farabi, A. (2010). Konsep Eco-Community Melalui Pengembangan Eco-Enzyme Sebagai Usaha Pengolahan Sampah Organik Secara Tuntas Pada Level Rumah Tangga. Kemampuan Koneksi Matematis (Tinjauan Terhadap Pendekatan Pembelajaran Savi), 53(9), 1689-1699

Megah, S. I., Dewi, D. S., \& Wilany, E. (2018). Pemanfaatan Limbah Rumah Tangga Digunakan Untuk Obat Dan Kebersihan. Minda Baharu, 2(1), 50. DOI: https://doi.org/10.33373/jmb.v2i1.2275

Pratiwi, N. (2020). Degradasi Sampah Organik dengan bantuan Maggot Black Soldier Fly. 3(2017), 54-67. http://repositorio.unan.edu.ni/2986/1/5624.pdf

Yunik'ati, Imam, R. M., Hariyadi, F., \& Choirotin, I. (2019). Sadar Pilah Sampah Dengan Konsep 4R (Reduce, Reuse, Recycle, Replace) Di Desa Gedongarum, Kanor, Bojonegoro. Jurnal Inovasi Hasil Pengabdian Masyarakat (JIPEMAS), 2(2), 81-87. DOI: https://doi.org/10.33474/jipemas.v2i2.1122

Yusuf, G. (2008). Bioremediasi limbah rumah tangga dengan sistem simulasi tanaman air. Bumi Lestari, 8(2), 136-144. 